she was an active member of the editorial board of the WSU Press. Her scholarly publications include Glossary of the Igor' Tale, as well as a translation of her father's study of Evgenii Onegin.

She was a cherished friend of many Slavists in the United States, and they will certainly remember her warmly for years to come.

\author{
KenNeTH N. BRostrom \\ Wayne State University \\ RALPH T. FISHER \\ University of Illinois, Urbana-Champaign
}

\title{
JAROSLAV ŠIDAK, 1903-1986
}

Jaroslav Šidak, professor emeritus of history at the University of Zagreb, died on 25 March 1986 under most grievous circumstances. With his passing Croatian historiography lost its most outstanding practitioner of the past four decades.

Born into a Czech family in Vienna, Jaroslav Šidak was brought up in Zagreb and completed all of his schooling there. He earned his doctoral degree in history with a thesis on "Problem bosanske crkve u našoj historiografiji od Petranovića do Glušca" (1935). After a brief period as a gymnasium instructor at Senj and Zagreb and work in the editorial board of Hrvatska enciklopedija, he was appointed an assistant professor of Croatian history at the University of Zagreb (1943), where he continued as an associate (1945) and full professor (1954) of modern European history. He held the chair of Croatian history from 1958 to his retirement in 1973.

Sidak was one of those rare historians who was utterly untouched by the conventions of specialization in historiography's various chambers-old and new. But unlike the generalists of earlier times he approached every field of inquiry with the command of a specialist. His research, consisting of over two hundred studies and articles, spanned the centuries of Croatian and south Slavic history from the reign of Demetrius Zvonimir to the intellectual maturation of Stjepan Radić. Quite obviously, this breadth was purchased by his absolute control of the sources and literature, something that made him impervious to every sort of self-important theories, mannerisms, and fads.

Šidak's work was dominated by four topics, each a combination of intellectual and political approaches to history. His earliest area of interest was medieval Bosnian neoManichaeism, whose mysteries he saw quite differently in various stages of his progress toward unmatched authority in this field. In his original conception (1935), Sidak saw the Church of Bosnia as an independent-but nonheretical-church organization derived from the Catholic diocese of Bosnia. This congregation was an expressly monastic church, continued many aspects of religious life derived from the Cyrillo-Methodian tradition, and separated itself from Rome in the 1230s in reaction to papal attempts to make it conform to Latin ecclesiastical and liturgical practices. In 1954, after much rethinking and after the publication of several new sources, Šidak increasingly accepted the classical thesis of Franjo Rački, whereby the Church of Bosnia was by provenance a neo-Manichean sect. Nevertheless, he continued to advance many convincing counter-proofs against supposed Bosnian dualist beliefs, convinced that the character of Bosnian doctrines was still far from clear.

Three other topics competed for Šidak's attention during the last four decades of his scholarly life. He was, first, the foremost twentieth century student of baroque Slavism among the Croats, his studies of Juraj Križanić and Pavao Ritter Vitezović being the great synthetic statements on the subjects. Second, Šidak was the greatest specialist in the history of Croatian revival and the Illyrianist movement, his distinction between cultural Illyrianism and political Croatism having ended many caprices of imagination 
that continued to distort the general perception of the revival. Third, Šidak was the greatest authority on the history of Croatian historiography. He was painfully aware that after him there would be hardly any candidates capable of writing an informed overview of this topic. It is a great cultural loss that his time ran out before the completion of this task.

Šidak's research alone would have sufficed more than one lifetime, but he was more than an authoritative scholar. Generations of students and colleagues--including many visitors from abroad-will remember him as an outstanding lecturer, adviser, mentor, gentleman, and friend. A pianist and the editor of Jugoslavenski muzičar in the 1920s, he had the ear for language, having set the aesthetic standard for historical writing in contemporary Croatian. But, most important, he gave institutional shape to a profession in rapid expansion in a period of many constraints. As the editor and founder of Historijski zbornik, the best historical journal in Yugoslavia, he encouraged the best work available, brooking no interference from any quarter. Šidak had little patience with les grands simplificateurs of various hues. This exposed him to many indignities, but his sovereign sway in historiography was almost never challenged intellectually. Jaroslav Šidak prized truth above all else: hence his characteristic stance of wonder that so many subverted this ideal so often.

Ivo BANAC

Yale University

\section{EDGAR H. LEHRMAN, 1926-1986}

Professor and chairman of the Russian Department at Washington University in St. Louis, Edgar H. Lehrman died of brain cancer on 24 July 1986, at age sixty. While in the USSR in 1962-1963 under the terms of the American-Soviet academic exchange, he married Ruth Makarova, a Moscow University student. True to form, the Soviet authorities tried hard to break up the international romance but ultimately relented and allowed the bride to depart. She survives, as do their three daughters, Tanya, Ellen, and Julie.

A native New Yorker, Edgar H. Lehrman held a bachelor's degree in English from Cornell and an M.A. as well as a doctorate in Slavic languages and literatures from Columbia. His dissertation dealt with Russian Shakespeare scholarship, and he also edited a volume of Turgenev's letters. There is no doubt, however, that he will be long and gratefully remembered, above all, as the author of guides to the Russian texts of several Russian literary classics, including Crime and Punishment, War and Peace, and a representative collection of eighty-six of Chekhov's short stories, the latter published shortly before his untimely death. All of these were intended as a teaching aid that would enable an American student with two to three years of college Russian, and armed only with a standard Russian-English dictionary, to negotiate his way through the original texts of these works, helping him with difficult idioms, grammatical irregularities, slang, references to exotic realia or to mysteries of history and geography. Compiling these was a heroic task, but Lehrman viewed it as his scholarly mission. The guides are, indeed, models of pedagogy that required inexhaustible patience and wide erudition. Edgar $\mathrm{H}$. Lehrman played another unique role. For seventeen years he served as a reviewer of Russian books-and books dealing with Russia-for the St. Louis Post-Dispatch. Alone in the United States, Lehrman had access to pages of a major daily that he used to inform readers not only of the usual literary and political best sellers, but also of serious scholarly studies in the field of Russian culture, history, and politics. An exceptionally modest and warm person, Lehrman was one of the few serious scholars whose work directly benefited 